BRIEF REPORT in DEVELOPMETRICS:

\title{
Children's Social Information Processing in Ambiguous Situations with Teachers: A Measure Development Study
}

\author{
Author: \\ Jantine L. Spilt \\ KU Leuven - University of Leuven \\ Jantine.spilt@kuleuven.be
}

Published in:

European Journal of Developmental Psychology

09 December 2019

Citation:

Spilt, J. L. (2019). Children's social information processing in ambiguous situations with teachers: A measure development study. European Journal of Developmental Psychology.

https://doi.org/10.1080/17405629.2019.1699402

\begin{abstract}
Children's atypical processing of social behavior of teachers may explain poor teacher-child relationships. To test this assumption, we developed the Social Information Processing in Teacher-child Interactions Test (SIP-TIT) and evaluated its psychometric properties. The SIPTIT examines children's SIP in ambiguous situations with teachers asking children to respond to 4 audio-taped hypothetical vignettes. The sample consisted of 302 primary school children $\left(M_{\text {age }}=10.75, S D=0.95\right)$ and 12 teachers. Children and teachers completed questionnaires on teacher-child relationships quality (closeness, conflict, and dependency) and teachers also rated child aggression. Scale reliability and construct validity were examined. Children's SIP and in particular hostile intent attribution was associated with child perceptions of poor teacher-child relationships. Hostile intent attribution and Rejection of prosocial response were associated with more aggression.
\end{abstract}

Key-words: social information processing, teacher-child relationship, aggression, measure development, hypothetical vignettes 


\section{Children's Social Information Processing in Ambiguous Situations with Teachers: A Measure Development Study}

Poor teacher-child relationships, in particular non-close and conflictual relationships, can have deleterious effects on children's cognitive and social development (McGrath \& Van Bergen, 2015; Pianta, 2001). Yet, little is known about the mechanisms that account for poor teacher-child relationships. Research has consistently shown that children's atypical social information processing (SIP) can explain interpersonal problems (Crick \& Dodge, 1994). To date, however, research has almost exclusively focused on SIP in hypothetical situations with peers, and far less so with adults (e.g., Dodge \& Price, 1994) or teachers (e.g., Samson \& Wehby, 2019; Wyatt \& Haskett, 2001).

SIP is a complex process. The basic premise is that the way children understand and interpret a particular social situation predicts whether they will respond aggressively or prosocially. SIP is a multi-stage process consisting of five separate mental steps in responding to social stimuli (Crick \& Dodge, 1994; Lemerise \& Arsenio, 2000). In step one, information is encoded: "What happened?". In the second step, the information is represented and interpreted: "Why did it happen?". This involves the representation of one's own and other people's emotions as well as attributions for others behaviors, e.g., "Was it an accident or did he/she do it on purpose?". Third, goals need to be clarified. Goals can be predominantly selffocused and instrumental aimed at displaying dominance or taking revenge, or prosocial aimed at maintaining a good relationship (Harper, Lemerise, \& Caverly, 2010). In steps four and five, possible responses are generated and evaluated in relation to goals and anticipated outcomes. Finally, a behavioral response is enacted.

Atypical SIP has been linked to the development of aggression and poor peer relationships (Orobio de Castro, Jan, Willem, Joop, \& Heidi, 2002). Arousal of negative emotions (anger) and the attribution of hostile intent in particular have been linked to aggressive behavior (Orobio de Castro, Merk, Koops, Veerman, \& Bosch, 2005), which, in turn, hinders the development of social relationships and consequently limits possibilities to learn social skills. Lansford et al. (2010) found maladaptive cascades between atypical SIP, peer rejection, and aggression.

Previous research predominantly studied SIP in the context of peer relationships. Some studies have included scenarios of ambiguous adult behavior but did not separate responses to peers or adults, assuming that SIP is fairly similar across relationship types (Dodge \& Price, 1994). More recently, however, it has been shown that children's SIP differs across relationships, for example between siblings, neutral peers, friends, and enemies (e.g., Peets, Hodges, Kikas, \& Salmivalli, 2007; Recchia, Rajput, \& Peccia, 2015).

Only a few researchers have studied children's processing of ambiguous or negative teacher behavior. It is assumed that negatively biased interpretations of teacher behavior are associated with aggressive behavior at school and in particular with conflictual relationships between teachers and children. A handful of studies provides first support for these assumptions. Bickett, Milich, and Brown (1996) found that aggressive boys attributed more hostile intent to ambiguous teacher behavior and reported more aggressive responses compared to non-aggressive boys. Wyatt and Haskett (2001) found similar results in a sample of aggressive and non-aggressive adolescents. Moreover, Samson and Wehby (2019) reported a small association between hostile attribution bias and teacher-rated conflict in a sample of primary school boys. These researchers have all used written vignettes to examine SIP in teacher-child interactions.

We developed a measure of children's SIP of ambiguous teacher behavior in line with measures used in peer research that utilize audiotaped hypothetical vignettes (Orobio de Castro et al., 2005). Unlike most other measures using a mix of open and closed-ended questions, our measure was developed for group-administration using closed-ended questions. 
We expect that atypical SIP including negatively biased interpretations of teacher behavior would be associated with aggressive behavior at school and teacher-child conflict. Understanding mechanisms that explain teacher-child confict is of crucial importance given that conflictual teacher-child relationships predict behavioral maladjustment and poor school performance above and beyond initial child problems (e.g., Stipek \& Miles, 2008).

We examined the measure's psychometric properties including its reliability and construct validity. For validation purposes, we tested a measurement model using confirmatory factor analysis and examined concurrent associations with qualities of the teacher-child relationship (both child- and teacher-reported) and child aggression at school. Teacher-child relationship quality was assessed in line with the three-factor model of teacherchild relationships (Koomen \& Jellesma, 2015; Pianta, 2001) including closeness (degree of warmth and open communication), conflict (distrust and coercion), and dependency (overly clingy student behavior).

\section{Sample}

\section{Method}

This study included a convenience sample of 302 children ( 154 boys, $M_{\text {age }}=10.75, S D=0.95$ ) from grades $4(n=103), 5(n=102)$, and $6(n=97)$ from one regular primary school. Almost all children and their parents (99\%) were born in the Netherlands. Twelve Dutch teachers (5 male) with on average 14 years of experience $(S D=7.2)$ completed questionnaires for a subsample of 8 randomly-selected students (four boys, four girls) in their class $(n=96)$.

The school was located in the densely populated Randstad area in the Netherlands in a new neighborhood. Of the parents of the school's student population, $73 \%$ had obtained a higher vocational degree or had completed higher education.

\section{Instruments}

Social information processing (SIP) of ambiguous teacher behavior. The Social Information Processing in Teacher-child Interactions Test (SIP-TIT) was developed to measure children's SIP in ambiguous situations with teachers. The SIP-TIT includes four vignettes and was first pilot-tested in a grade-4 classroom $(\mathrm{N}=14)$. Written feedback from students was collected, indicating that children understood the measure. The SIP-TIT is attached as supplementary material.

Part A. The initial version of the SIP-TIT (Part A) was developed to measure children's representation and interpretation of ambiguous teacher behavior (step 2 of SIP). Children listened to 4 audiotaped vignettes (e.g., a teacher gives unhelpful feedback; a teacher forgets a promise), each followed by several questions. Children were first asked to write down how they would feel in a similar situation (open-ended question; not scored). Children then were asked to rate four emotions on 4-point scales (1=Not at all; 4=Very much) including anger, frustration, insecurity, and disappointment (i.e., "How angry/frustrated/insecure/ disappointed would you be"). Two scales were constructed measuring Anger/frustration and Insecurity/disappointment. Negative Emotion Attribution was measured including two teacher emotions, anger and disappointment (i.e., "How angry/disappointed would your teacher be"). Hostile Intent Attribution was measured by three propositions providing negative explanations for the teacher's behavior (e.g., 'Because my teacher doesn't like me'), rated on 5-point scales ( $1=$ not applicable at all, 5=very applicable). Benign Intent attribution was measured by one proposition providing a neutral explanation (e.g., 'Because it happened by accident').

Pilot test. The measure was administered in a sample of 182 children and 10 teachers from 5 different primary schools. Significant correlations were found with both child-reported ( $r$ s between .17 and $.46, p<.05$ ) and teacher-reported teacher-child relationships ( $r s$ between .15 and $.17, p<.05)$, and with conduct problems $(r=.13, p<.05)$ and prosocial behavior $(r=-.17, p<.05$; Author, 2011). 
Part B. The SIP-TIT was then extended to measure goal and response evaluation as well (step 3 and 5 of SIP). Part B employed 4 audiotaped vignettes in which hypothetical children were asked by their teacher to do something in an ambiguous, provocative situation that could be evaluated as 'unfair'. Each vignette was followed by three questions. Children were asked whether they found it important to avoid problems with the teacher in that particular situation (1=not important at all; 4=very important) to measure children's evaluation of an Interpersonal goal (step 3: evaluation of goals). The final two questions refer to response evaluation (step 5). Children were asked whether they would obey the teacher (1=yes, surely; $4=$ no, surely not). A high score represents the intention to oppose the teacher (Oppositional response). Lastly, students were asked whether they would go and talk to the teacher about the problem ( $1=y e s, 2=$ maybe, $3=$ no): a high score reflects the tendency to Reject a prosocial response.

Teacher-child relationship quality. Child perceptions of the teacher-child relationship were assessed with the Student Perception of Affective Relationship with Teacher Scale (SPART, Koomen \& Jellesma, 2015). Children rated 22 items $(1=$ no, that is not true; 5=yes, that is true) measuring Closeness (e.g., When I feel uncomfortable, I go to my teacher for help and comfort; $\alpha=.74$ ), Conflict (e.g., I easily have quarrels with my teacher; $\alpha=.77$ ) and Dependency or Negative Expectations (e.g., I wish my teacher could spend more time with me; $\alpha=.68$ ). Support was found for factorial and construct validity in a Dutch sample of children in grades 4-6 (Koomen \& Jellesma, 2015).

Teacher perceptions were assessed with a single item per dimension (to avoid teacher overload) describing a Close relationship ("This student can get along with his/her teacher. The student likes talking to his/her teacher and the teacher enjoys spending time with the student"), a Conflictual relationship ("This student cannot get along with his/her teacher. The student and his/her teacher often disagree or quarrel"), and a Dependent relationship ("This student often wants to be close to his/her teacher. The student seeks help in situations when he/she really does not need help"). Teachers rated the applicability of these descriptions for a student (1=Definitely does not apply; 5=Definitely applies). Consistent with previous research, convergence between teacher and child reports was small to moderate ( $r \mathrm{~s}=.17-.34)$ and there was a large correlation between teacher-reported conflict and frequency of aggressive behavior $(r=.69)$ in the current sample.

Aggressive behavior. Teachers also completed the Instrument for Reactive and Proactive Aggression (IRPA: Polman, De Castro, Thomaes, Van Aken, 2009) to measure the overall frequency of physical (e.g., hitting), verbal (e.g., name calling), and covert (e.g., gossiping) aggression at school on a 4-point scale ( $0=$ never, $4=$ daily; $\alpha=.92)$. Construct validity has been demonstrated in a Dutch sample of children in grades 5-6.

\section{Procedure}

Passive informed consent forms were send to parents of 320 children. Consent was given for 317 children of which 15 children were absent during administration. Identifier codes (instead of children's names) were used for anonymous data collection. The instruments were group-administered to the children in school by a researcher while the teacher completed the questionnaires in a separate room. Children individually completed the SIP-TIT and the questionnaires (they read and answered the questions silently). It was assured that no wrong answers could be given and that the answers would be confidential.

\section{Analytic strategy}

Confirmatory factor analyses and regression analyses were performed in Mplus (Muthén \& Muthén, 1998-2015) using Full Information Maximum Likelihood (FIML) estimation to account for missing data and the robust maximum likelihood (MLR) estimation to account for cluster variance (children nested in teachers). Regression analyses were performed to examine unique associations between the SIP-TIT and the outcomes. 
The covariance coverage matrix provides information on the extent of missing data. The covariance coverage ranged between .977 and 1.00 across all data points. Item-level missingness ranged between $0 \%$ and $1.3 \%$ across SIP Part A items and between $0 \%$ and $0.7 \%$ across SIP Part B items. A total of 287 children had no missings on part A items $(5.0 \%$ incomplete cases) and 300 children had no missings on part B items ( $0.7 \%$ incomplete cases). Scale scores were based on available items. One child that did not complete the SPARTS. Teacher completed all questionnaires.

\section{Results}

We conducted confirmatory factor analyses. We modelled the influence of vignettes (i.e., method effects) by allowing observed items to load on its corresponding vignette. Trait effects were measured by allowing the observed items to load on their corresponding trait. Trait and method variables were not allowed to correlate. Trait variables were allowed to correlate (see Figure S1 in Supplementary Material). Standardized trait loadings ranged between .49 and .62 for Anger/frustration, between .42-.58 for Insecurity/disappointment, between .11 and .76 for Negative Emotion Attribution, between .58 and .79 for Hostile Intent Attribution, and between .21 and .72 for Benign Intent Attribution (Model fit: $\chi^{2}(690, N=302)=1377, p<.00$; RMSEA=.057; SRMR=.071; CFI=.814).

For Part B, we examined a separate measurement model. Standardized trait loadings ranged between .62 and .80 for Interpersonal goal, between .64-.69 for Oppositional response, between .51 and .56 for Reject a prosocial response (Model fit: $\chi^{2}(39, N=302)=58.22, p=.02$; $\mathrm{RMSEA}=.040$; $\mathrm{SRMR}=.043 ; \mathrm{CFI}=.976$ ). The full model results are available from the author upon request.

In the next step, scale scores were constructed by averaging corresponding items. The descriptive statistics are presented in Table 1. The internal consistency scores (McDonalds omega) ranged between .58 and .93 . Small to moderate correlations were found between subscales. The strongest correlations were observed between Anger, Negative Intent Attribution, and Oppositional Response selection ( $r s=.38-.46$; Table 1): this is in line with findings that emotion variables and hostile intent attribution are key in explaining antisocial or oppositional behavior (cf. Orobio et al., 2005).

All SIP-TIT scales, with the exception of Interpersonal goal endorsement, were uniquely associated with one or more outcomes (Table 2). Hostile intent attribution showed the strongest effects. The SIP-TIT could not explain variance in teacher-rated Dependency. For zero-order correlations between the SIP-TIT and the outcomes, see Table S1, Supplementary Material.

\section{Discussion}

The aim of this study was to obtain a measure of children's SIP in interactions with teachers. To this end, a vignette measure of ambiguous teacher behavior was developed and we tested the reliability and construct validity of the measure.

Most SIP-TIT scales showed good internal consistency but Benign intent attributions and Rejection prosocial response were below .70 and need additional attention. In general, adding items or vignettes could improve the scales.

The correlations between the scales were low to moderate and almost all scales were uniquely associated with teacher or child-reported relationship dimensions. This indicates that each scale may have a unique contribution to our understanding of poor teacher-child relationships. Only endorsement of a prosocial goal (Interpersonal goal; Table 2) was not uniquely associated with the outcomes. Although this scale correlated with all child-reported teacher-child relationship dimensions (Table S1 in Supplementary Material), these associations were no longer significant when other SIP-variables were included in the analysis (Table 2). As expected, Hostile intent attribution (e.g., interpreting a teacher's behavior as 
intentionally unfair or harsh) was most strongly and consistently associated with relationship quality and with aggression.

Associations with aggression were also found. Children who were rated as more aggressive, were more inclined to attribute hostile intent to ambiguous behavior of a (hypothetical) teacher and were also more inclined to reject a prosocial response. The association between hostile intent attribution and aggression was, although moderate, stronger than expected in a non-clinical, gender-mixed sample (cf. Orobio et al., 2002, 2005).

Overall, the magnitude of the correlations with teachers' relationship reports was small (i.e., $r s \leq .20$; see Table S1 in Supplementary Materials), but not lower than in other recent research (cf. Samson \& Wehby, 2019). Only one unique association was found (Table 2). Together, these patterns of results provide first support for the construct validity of the SIPTIT.

Not all SIP-measures distinguish between negative emotions like anger and insecurity (cf. Murphy \& Eisenberg, 2002). In this study, both anger/frustration and insecurity/disappointment were related to hostile intent attributions. However, whereas anger was related to oppositional response selection, insecurity was related to pursuing an interpersonal goal (Table 1), deeming it more important to avoid getting into conflict with the teachers and to talk to the teacher than to oppose the teacher. Also, feelings of insecurity were uniquely associated with dependent teacher-child relationships (Table 2). This is an important finding because dependency is a poorly understood and neglected dimension of the teacherchild relationship (McGrath \& Van Bergen, 2015).

The low CFI of .814 of the measurement model implies that there is room for improvement. First, attention should be given to the relatively low reliability and item factor loadings of the subscale Benign attributional bias, because attributions of benign intent may particularly facilitate positive teacher-child relationships. Likewise, some of the trait loadings of the items of Negative Emotion Attribution were low and it may be questioned whether all vignettes (in particular Vignette 1 and 2: see Supplementary Material) were fit to assess this construct. In addition, the measure can be extended by including aspects of SIP that were not measured in this first version: encoding of relevant information, emotion regulation strategies, response generation, and outcome expectancies. Finally, it should be noted that this study included a convenience sample in a single school, and does now allow for generalizations to the population. Future research is needed to examine discriminant validity (e.g., compare predictive effects above and beyond measures of SIP in ambiguous situations with peers) and predictive validity.

In conclusion, this study provides first support for the SIP-TIT as a measure of children's social information processing in ambiguous situations with teachers. Negative emotional arousal and internalized schemas of teachers as unfair may explain the negative transactional effects between externalizing problems and teacher-child conflict that have been seen in previous research (Doumen et al., 2008).

\section{References}

Author, 2011. Teacher-child relationships and children's social information processing in ambiguous hypothetical situations with teachers. Biennial Meeting of the Society for Research in Child Development. Montreal, April 2011.

Arsenio, W. F., Adams, E., \& Gold, J. (2009). Social information processing, moral reasoning, and emotion attributions: Relations with adolescents' reactive and proactive aggression. Child Development, 80(6), 1739-1755.

Bickett, L. R., Milich, R., \& Brown, R. T. (1996). Attributional styles of aggressive boys and their mothers. Journal of Abnormal Child Psychology, 24(4), 457-472.

Crick, N. R. \& Dodge, K. A. (1994). A review and reformulation of social-information- 
processing mechanisms in children's social adjustment. Psychological Bulletin, 115, 74-101.

Dodge, K. A., \& Price, J. M. (1994). On the relation between social information processing and socially competent behavior in early school-aged children. Child Development, 65(5), 1385-1397.

Doumen, S., Verschueren, K., Buyse, E., Germeijs, V., Luyckx, K., \& Soenens, B. (2008). Reciprocal relations between teacher-child conflict and aggressive behavior in kindergarten: A three-wave longitudinal study. Journal of Clinical Child and Adolescent Psychology, 37(3), 588-599.

Harper, B., Lemerise, E., \& Caverly, S. The effect of induced mood on children's social information processing: Goal clarification and response decision. Journal of Abnormal Child Psychology, 38(5), 575-586.

Koomen, H. M., \& Jellesma, F. C. (2015). Can closeness, conflict, and dependency be used to characterize students' perceptions of the affective relationship with their teacher? Testing a new child measure in middle childhood. British Journal of Educational Psychology, 85(4), 479-497.

Lemerise, E. A., \& Arsenio, W. F. (2000). An integrated model of emotion processes and cognition in social information processing. Child Development, 71, 107-118.

Lansford, J. E., Malone, P. S., Dodge, K. A., Pettit, G. S., \& Bates, J. E. (2010). Developmental cascades of peer rejection, social information processing biases, and aggression during middle childhood. Development and Psychopathology, 22(3), 593602.

McGrath, K. F., \& Van Bergen, P. (2015). Who, when, why and to what end? Students at risk of negative student-teacher relationships and their outcomes. Educational Research Review, 14, 1-17.

Murphy, B. C., \& Eisenberg, N. (2002). An integrative examination of peer conflict: Children's reported goals, emotions, and behaviors. Social Development, 11(4), 534557.

Muthén, L.K. and Muthén, B.O. (1998-2015). Mplus User's Guide. Seventh Edition. Los Angeles, CA: Muthén \& Muthén

Orobio de Castro, B., Jan, W. V., Willem, K., Joop, D. B., \& Heidi, J. M. (2002). Hostile Attribution of Intent and Aggressive Behavior: A Meta-Analysis. Child Development, 73(3), 916-934.

Orobio de Castro, B., Merk, W., Koops, W., Veerman, J. W., \& Bosch, J. D. (2005). Emotions in social information processing and their relations with reactive and proactive aggression in referred aggressive boys. Journal of Clinical Child \& Adolescent Psychology, 34(1), 105 - 116.

Pianta, R. C. (2001). Student-teacher relationship scale: Professional manual. Psychological Assessment Resources.

Recchia, H. E., Rajput, A., \& Peccia, S. (2015). Children's interpretations of ambiguous provocation from their siblings: Comparisons with peers and links to relationship quality. Social Development, 24(4), 782-797.

Peets, K., Hodges, E. V., Kikas, E., \& Salmivalli, C. (2007). Hostile attributions and behavioral strategies in children: Does relationship type matter? Developmental Psychology, 43(4), 889.

Polman, H., de Castro, B. O., Thomaes, S., \& van Aken, M. (2009). New directions in measuring reactive and proactive aggression: Validation of a teacher questionnaire. Journal of Abnormal Child Psychology, 37(2), 183-193.

Samson, J. E., \& Wehby, J. H. (2019). Children's attributions about teachers' intentions. Psychology in the Schools, 56(2), 220-231. 
Stipek, D., \& Miles, S. (2008). Effects of aggression on achievement: Does conflict with the teacher make it worse?. Child development, 79(6), 1721-1735.

Wyatt, L. W., \& Haskett, M. E. (2001). Aggressive and nonaggressive young adolescents' attributions of intent in teacher/student interactions. The Journal of Early Adolescence, 21(4), 425-446. 
Tables

Table 1. Descriptive Statistics of the SIP-TIT

\begin{tabular}{|c|c|c|c|c|c|c|c|c|c|}
\hline & $\begin{array}{c}\text { McDonald's } \\
\text { omega }\end{array}$ & $M(S D)$ & 1 & 2 & 3 & 4 & 5 & 6 & 7 \\
\hline \multicolumn{10}{|l|}{ Interpretation: own emotions } \\
\hline 1.Anger & .80 & $2.61(0.59)$ & & & & & & & \\
\hline 2.Insecurity & .78 & $2.43(0.55)$ & $.46^{* *}$ & & & & & & \\
\hline \multicolumn{10}{|l|}{ Interpretation: teacher emotions } \\
\hline 3.Negative emotion attributions & .71 & $1.88(0.41)$ & $.31 * *$ & $.37 * *$ & & & & & \\
\hline \multicolumn{10}{|l|}{ Interpretation: teacher behavior } \\
\hline 4.Hostile intent attributions & .92 & $1.38(0.51)$ & $.41 * *$ & $.21 * *$ & $.18 * *$ & & & & \\
\hline 5.Benign intent attributions & .58 & $3.58(0.75)$ & $-.15^{* *}$ & .05 & -.05 & $-.37 * *$ & & & \\
\hline \multicolumn{10}{|l|}{ Goal evaluation: } \\
\hline 6.Interpersonal goal & .93 & $2.60(0.72)$ & $-.20 * *$ & $.11 *$ & -.05 & $-.26 * *$ & $.19 * *$ & & \\
\hline \multicolumn{10}{|l|}{ Response evaluation: } \\
\hline 7.Oppositional response & .78 & $2.16(0.66)$ & $.46^{* *}$ & .01 & $.15^{* *}$ & $.38 * *$ & $-.16^{* *}$ & $-.44 * *$ & \\
\hline 8.Rejection prosocial response & .62 & $1.88(0.53)$ & -.06 & $-.22 * *$ & -.03 & $.15^{* *}$ & $-.17 * *$ & $-.23 * *$ & -.00 \\
\hline
\end{tabular}

Note: $* * p \leq .01,{ }^{*} p \leq .05$ (two-tailed) 
Table 2. Prediction of Teacher-Child Relationship Quality and Aggression rated by Children $(N=302)$ and Teachers $(n=96)$

\begin{tabular}{|c|c|c|c|c|c|c|c|c|c|c|c|c|c|c|}
\hline & \multicolumn{2}{|c|}{ Closeness-C } & \multicolumn{2}{|c|}{ Conflict-C } & \multicolumn{2}{|c|}{ Dependency-C } & \multicolumn{2}{|c|}{ Closeness-T } & \multicolumn{2}{|c|}{ Conflict-T } & \multicolumn{2}{|c|}{ Dependency-T } & \multicolumn{2}{|c|}{ Aggression- $\mathrm{T}$} \\
\hline & $B(S E)$ & $\beta$ & $B(S E)$ & $\beta$ & $B(S E)$ & $\beta$ & $B(S E)$ & $\beta$ & $B(\overline{S E})$ & $\beta$ & $B(S E)$ & $\beta$ & $B(S E)$ & $\beta$ \\
\hline \multicolumn{15}{|l|}{ SIP-TIT } \\
\hline scales: & & & & & & & & & & & & & & \\
\hline Anger & $\begin{array}{l}-0.23 \\
(0.09)^{* *}\end{array}$ & -0.17 & $\begin{array}{l}0.15 \\
(0.08)^{*}\end{array}$ & 0.16 & $\begin{array}{l}0.04 \\
(0.07)\end{array}$ & 0.03 & $\begin{array}{l}-0.31 \\
(0.19)\end{array}$ & -0.22 & $\begin{array}{l}-0.24 \\
(0.18)\end{array}$ & -0.23 & $\begin{array}{l}-0.11 \\
(0.23)\end{array}$ & -0.05 & $\begin{array}{l}-0.05 \\
(0.09)\end{array}$ & -0.05 \\
\hline Insecurity & $\begin{array}{l}0.19 \\
(0.09)^{*}\end{array}$ & 0.13 & $\begin{array}{l}-0.13 \\
(0.07)^{*}\end{array}$ & -0.13 & $\begin{array}{l}0.32 \\
(0.10) * *\end{array}$ & 0.28 & $\begin{array}{l}0.0 .24 \\
(0.15)\end{array}$ & 0.16 & $\begin{array}{l}0.26 \\
(0.17)\end{array}$ & 0.24 & $\begin{array}{l}0.24 \\
(0.24)\end{array}$ & 0.11 & $\begin{array}{l}0.09 \\
(0.20)\end{array}$ & 0.08 \\
\hline $\begin{array}{l}\text { Negative } \\
\text { emotion } \\
\text { attributions }\end{array}$ & $\begin{array}{l}0.03 \\
(0.12)\end{array}$ & 0.02 & $\begin{array}{l}0.03 \\
(0.05)\end{array}$ & 0.03 & $\begin{array}{l}0.07 \\
(0.07)\end{array}$ & 0.04 & $\begin{array}{l}-0.01 \\
(0.14)\end{array}$ & -0.00 & $\begin{array}{l}-0.30 \\
(0.17)^{*}\end{array}$ & -0.23 & $\begin{array}{l}0.28 \\
(0.30)\end{array}$ & 0.11 & $\begin{array}{l}-0.33 \\
(0.24)\end{array}$ & -0.26 \\
\hline $\begin{array}{l}\text { Hostile } \\
\text { intent } \\
\text { attribution }\end{array}$ & $\begin{array}{l}-0.59 \\
(0.11)^{* *}\end{array}$ & -0.38 & $\begin{array}{l}0.54 \\
(0.07)^{* *}\end{array}$ & 0.50 & $\begin{array}{l}0.49 \\
(0.06) * *\end{array}$ & 0.40 & $\begin{array}{l}-0.18 \\
(0.30)\end{array}$ & -0.10 & $\begin{array}{l}0.19 \\
(0.14)\end{array}$ & 0.15 & $\begin{array}{l}-0.07 \\
(0.30)\end{array}$ & -0.03 & $\begin{array}{l}0.37 \\
(0.19)^{*}\end{array}$ & 0.29 \\
\hline $\begin{array}{l}\text { Benign } \\
\text { intent } \\
\text { attribution }\end{array}$ & $\begin{array}{l}0.12 \\
(0.05)^{*}\end{array}$ & 0.12 & $\begin{array}{l}0.10 \\
(0.05)^{*}\end{array}$ & 0.13 & $\begin{array}{l}0.02 \\
(0.05)\end{array}$ & 0.03 & $\begin{array}{l}0.21 \\
(0.18)\end{array}$ & 0.17 & $\begin{array}{l}0.14 \\
(0.10)\end{array}$ & 0.15 & $\begin{array}{l}0.04 \\
(0.13)\end{array}$ & 0.02 & $\begin{array}{l}0.10 \\
(0.11)\end{array}$ & 0.12 \\
\hline $\begin{array}{l}\text { Inter- } \\
\text { personal } \\
\text { goal }\end{array}$ & $\begin{array}{l}0.02 \\
(0.05)\end{array}$ & 0.02 & $\begin{array}{l}-0.04 \\
(0.03)\end{array}$ & -0.05 & $\begin{array}{l}-0.07 \\
(0.05)\end{array}$ & -0.08 & $\begin{array}{l}0.09 \\
(0.15)\end{array}$ & 0.08 & $\begin{array}{l}-0.06 \\
(0.10)\end{array}$ & -0.07 & $\begin{array}{l}-0.20 \\
(0.16)\end{array}$ & -0.12 & $\begin{array}{l}0.07 \\
(0.13)\end{array}$ & 0.08 \\
\hline $\begin{array}{l}\text { Opposi- } \\
\text { tional } \\
\text { response }\end{array}$ & $\begin{array}{l}-0.06 \\
(0.07)\end{array}$ & -0.05 & $\begin{array}{l}0.10 \\
(0.06)\end{array}$ & 0.12 & $\begin{array}{l}-0.08 \\
(0.04)^{*}\end{array}$ & -0.09 & $\begin{array}{l}0.01 \\
(0.24)\end{array}$ & 0.01 & $\begin{array}{l}0.19 \\
(0.10)\end{array}$ & 0.20 & $\begin{array}{l}-0.04 \\
(0.21)\end{array}$ & -0.02 & $\begin{array}{l}0.14 \\
(0.15)\end{array}$ & 0.16 \\
\hline $\begin{array}{l}\text { Rejection } \\
\text { prosocial } \\
\text { response }\end{array}$ & $\begin{array}{l}-0.28 \\
(0.09)^{* *}\end{array}$ & -0.19 & $\begin{array}{l}-0.04 \\
(0.06)\end{array}$ & -0.03 & $\begin{array}{l}0.05 \\
(0.07)\end{array}$ & 0.04 & $\begin{array}{l}-0.11 \\
(0.15)\end{array}$ & -0.07 & $\begin{array}{l}0.05 \\
(0.10)\end{array}$ & 0.04 & $\begin{array}{l}-0.29 \\
(0.21)\end{array}$ & -0.13 & $\begin{array}{l}0.19 \\
(0.07)^{*}\end{array}$ & 0.16 \\
\hline$R^{2}$-value & & $.35 * *$ & & $.36 * *$ & & $.30 * *$ & & $.11 *$ & & $.15 *$ & & .05 & & $.17 *$ \\
\hline
\end{tabular}




\section{SUPPLEMENTARY MATERIALS}

Table S1. Correlations of the SIP-TIT with Teacher-Child Relationship Quality and Aggression

\begin{tabular}{|c|c|c|c|c|c|c|c|}
\hline & \multicolumn{3}{|c|}{ Child-rated $(N=302)$} & \multicolumn{3}{|c|}{ Teacher-rated $(n=96)$} & \multirow[b]{2}{*}{ Aggression } \\
\hline & Closeness & Conflict & Dependency & Closeness & Conflict & Dependency & \\
\hline \multicolumn{8}{|l|}{ Descriptive statistics } \\
\hline$M$ & 3.60 & 1.67 & 1.88 & 4.14 & 1.33 & 2.07 & 0.47 \\
\hline$S D$ & 0.80 & 0.55 & 0.63 & 0.85 & 0.63 & 1.21 & 0.61 \\
\hline \multicolumn{8}{|l|}{ Correlations with } \\
\hline SIP-TIT & & & & & & & \\
\hline Anger & $-.27 * *$ & $.36 * *$ & $.30 * *$ & $-.19 *$ & -.03 & .09 & .11 \\
\hline Insecurity & .03 & .07 & $.38 * *$ & -.02 & .09 & .14 & .08 \\
\hline $\begin{array}{l}\text { Negative emotion } \\
\text { attributions }\end{array}$ & -.05 & $.13^{*}$ & $.21 * *$ & -.07 & $-.19 *$ & .13 & -.11 \\
\hline $\begin{array}{l}\text { Hostile intent } \\
\text { attributions }\end{array}$ & $-.48 * *$ & $.57 * *$ & $.46 * *$ & $-.20 *$ & .12 & .00 & $.37 * *$ \\
\hline $\begin{array}{l}\text { Benign intent } \\
\text { attributions }\end{array}$ & $.30 * *$ & $-.11 *$ & $-.11 *$ & $23^{*}$ & .07 & .03 & -.02 \\
\hline Interpersonal goal & $.24 * *$ & $-.24 * *$ & $-.12 *$ & .13 & -.13 & -.08 & -.06 \\
\hline Oppositional response & $-.27 * *$ & $.38 * *$ & $.11^{*}$ & $-.18 *$ & $.18^{*}$ & .05 & $.35^{* *}$ \\
\hline $\begin{array}{l}\text { Rejection prosocial } \\
\text { response }\end{array}$ & $-.27 * *$ & .05 & .04 & -.07 & .04 & -.13 & .09 \\
\hline
\end{tabular}

Note: $* * p \leq .01, * p \leq .05$ (two-tailed) 


\section{Latent traits}

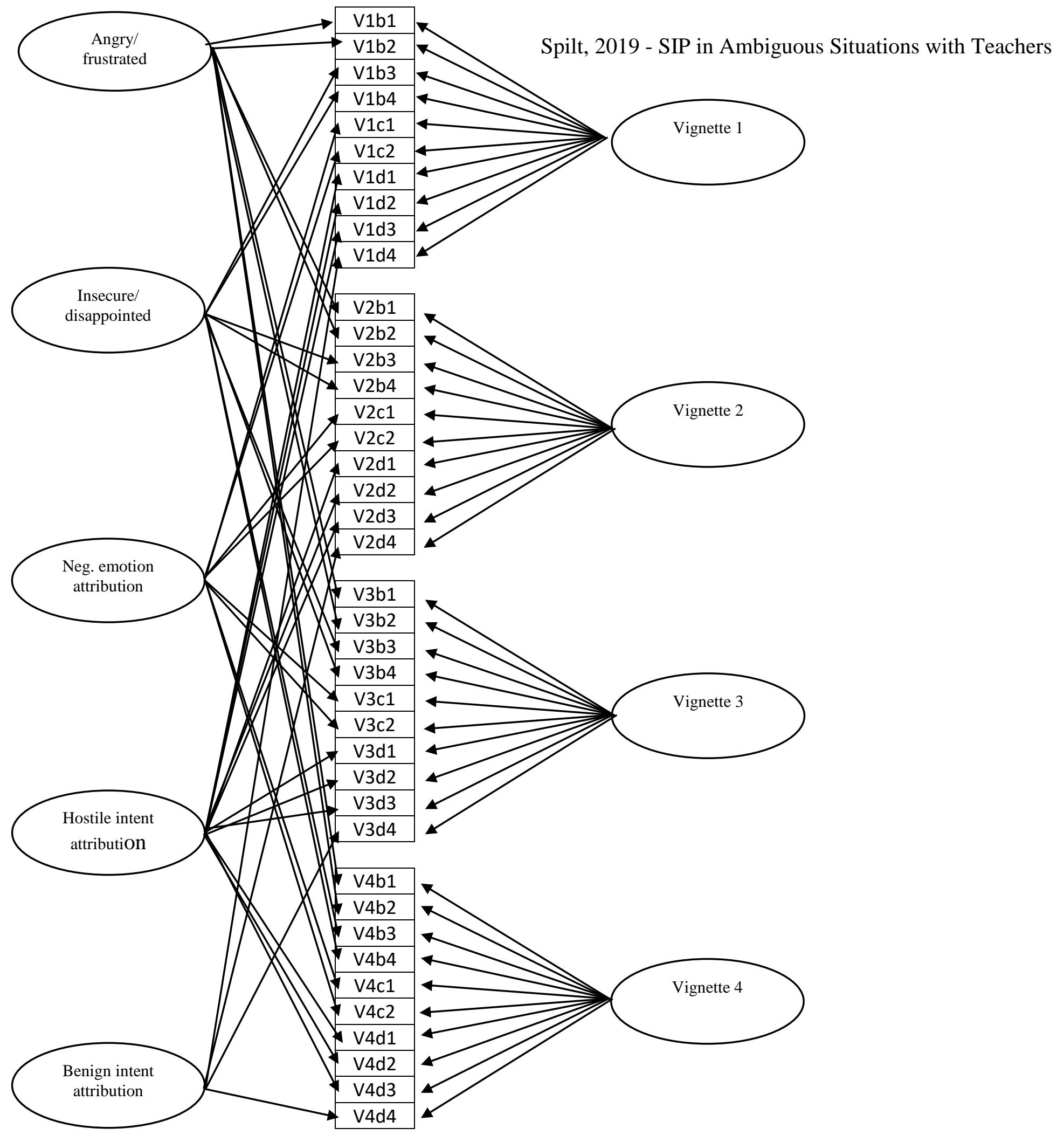

Figure S1. Measurement model.

Note 1. Observed variables are depicted in order of assessment. Trait factors were allowed to correlate but these covariances are not depicted for visual clarity.

Note 2. Explanation observed variables: $\mathrm{v}=$ vignette, $\mathrm{b} 1=$ angry, $\mathrm{b} 2=$ frustrated, $\mathrm{b} 3=$ insecure, $\mathrm{b} 4=$ disappointed, $\mathrm{c} 1=$ teacher angry, $\mathrm{c} 2=$ teacher disappointed, $\mathrm{d} 1-\mathrm{d} 3=$ propositions providing negative explanations for the teacher's behavior (e.g., 'Because my teacher doesn't like me'), $\mathrm{d} 4=$ proposition providing a neutral explanation (e.g., "it happened by accident")

Note 3. The full results are available upon request from the first author. 


\title{
Vignettes + questionnaire
}

\author{
(in Dutch, with English translation)
}

Note: there are different versions for 'meesters' [male teachers] en 'juffen' [female teachers)

\section{Deel A [Part A] : Vignettes}

\section{Vignette A1}

De kinderen in de klas hebben een werkstuk gemaakt. Peter heeft het onderwerp snoep gekozen. Hij krijgt een onvoldoende voor zijn werkstuk. Het is echt niet goed, hij moet het over doen.

\section{Vignette A2}

Robin zit goed naar de juf [meester] te luisteren, maar de andere kinderen in zijn groepje zitten allemaal te praten. Hij kan de uitleg daardoor niet goed horen. De juf kijkt Robin streng aan en vraagt wat ze net heeft uitgelegd. Robin heeft het niet gehoord en kan geen antwoord geven. De juf zegt tegen Robin: 'Wil je nu eindelijk eens opletten!'

\section{Vignette $\mathrm{A} 3$}

Na de vakantie wil Marijn graag over haar vakantie in Egypte vertellen. Tijdens de kring vertellen veel kinderen over hun vakantie, maar dan is de tijd om. De juf [meester] belooft dat Marijn morgen mag verder vertellen. De volgende dag gaat Marijn blij naar school, hij mag zijn verhaal gaan vertellen. Als de tijd om is, heeft Marijn weer geen beurt gekregen.

\section{Vignette A4}

Gisteren moest de hele klas een rekentoets maken. Nicky en Bo hadden beiden de toets erg goed gemaakt. De juf [meester] zegt tegen Nicky: 'Knap van je dat jij de toets zo goed gemaakt hebt!.' Tegen Bo zegt ze niets.

\section{Vignette A1 (translated)}

The children in the class have written a paper. Peter has chosen the subject of candy. He gets a poor grade for his paper. It's really not good, he has to do it again.

Vignette A2 (translated)

Robin is listening well to the teacher but the other children in his group are all talking. As a result, he cannot hear the teacher's explanation very well. The teacher looks at Robin sternly and asks to repeat what she has just explained. Robin has not heard it and cannot answer. The teacher says to Robin: "Please pay attention now!"

Vignette A3 (translated)

After the holidays, Marijn would like to talk about her holiday in Egypt. Many children talk about their holidays during circle time, but then the time is up. The teacher promises that Marijn can tell about her holidays tomorrow. The next day Marijn goes to school happily, she can tell her story. However, when the time is up, Marijn again has had no turn.

Vignette A4 (translated)

Yesterday, the class had to take a math test. Nicky and Bo both did well on the test. The teacher says to Nicky: "Well done, you did great!" She says nothing to Bo. 


\section{Deel B [Part B]: Vignettes}

\section{Vignette B1}

Jan speelt een computerspel samen met Peter, wat eigenlijk niet mag van de meester [juf]. Het is een heel spannend spel. Jan denkt dat hij gaat winnen. Plotseling komt hun meester binnenlopen. Hij zegt tegen Jan dat hij moet stoppen met het computerspel, omdat hij zijn taalles nog niet af heeft. Tegen Peter zegt de meester niets.

\section{Vignette B2}

Het is middagpauze. Joas heeft in zijn ene hand een beker melk en in zijn andere had een boterham met pindakaas. Caroline rent achter haar vriendinnetje aan, terwijl iedereen weet dat je niet mag rennen in de klas. Ze stoot ook nog tegen Joas aan waardoor de beker met melk op de grond valt. De juf [meester] heeft het gezien en zegt tegen Joas hij het moet opruimen. Tegen Caroline zegt ze niets.

\section{Vignette B3}

Het is donderdagmiddag. De juf [meester] legt een moeilijke rekensom uit aan de klas. Chris luistert niet goed, omdat Tjibbe fluisterend vertelt over het hondje die hij voor zijn verjaardag heeft gekregen. Chris fluistert terug dat hij ook graag een hondje wil. De juf kijkt Chris aan en zegt dat hij nu stil moet zijn. Tegen Tjibbe zegt ze niets.

\section{Vignette B4}

Janneke heeft net haar rekenles af. Janneke vraagt aan de juf [meester] of ze mag gaan spelen. De juf zegt dat ze Roos wel even kan gaan helpen met de sommen, omdat Roos de sommen niet zo goed begrijpt. Maar Janneke wil veel liever gaan spelen. De juf zegt: Nee, jij gaat Roos maar even helpen. Tim en Floortje, de vrienden van Janneke, zijn ook klaar. Zij mogen wel van de juf gaan spelen.

\section{Vignette B1 (translated)}

Jan plays a computer game with Peter, which is actually not allowed by the teacher. It is a very exciting game. Jan thinks he's going to win. Suddenly their teacher comes in. He tells Jan to stop the computer game, because he has not yet finished his language lesson. The teacher says nothing to Peter.

\section{Vignette B2 (translated)}

It is lunch break. Joas has a cup of milk in one hand and a peanut butter sandwich in the other. Caroline runs after her girlfriend, while everyone knows you are not allowed to run in the classroom. She also bumps into Joas, causing the cup of milk to fall on the floor. The teacher has seen it and tells Joas to clean it. She says nothing to Caroline.

\section{Vignette B3 (translated)}

It is Thursday afternoon. The teacher explains a difficult math task to the class. Chris doesn't listen well, because Tjibbe whispers in his ear about the dog he just got for his birthday. Chris whispers back that he also wants a dog. The teacher looks at Chris and tells him to be quiet now. She says nothing to Tjibbe.

Vignette B4 (translated)

Janneke has just finished her math lesson. Janneke asks the teacher if she can go play now. The teacher says that she can help Rose with her math task, because Roos needs help. But Janneke would rather like to play. The teacher says: No, you are going to help Rose. Tim and Floortje, Janneke's friends, have also finish their tasks. They may go and play from the teacher. 


\section{Gebeurtenissen in de klas/ Situations in the classroom (Juf-versie)}

Dit is een vragenlijst die gaat over situaties die je kunt meemaken op school en over je gevoel in dit soort situaties.

We zouden je willen vragen deze vragenlijst in te vullen en om zo eerlijk mogelijk te antwoorden. De vragenlijst is anoniem, dat betekent dat niemand jouw antwoorden te zien krijgt.

De verhaaltjes in deze vragenlijst gaan over situaties met je juf op school. Het kan zijn dat je zo'n situatie nog nooit hebt meegemaakt, maar je kunt je misschien wel voorstellen dat iemand anders heeft meegemaakt en hoe je je in zo'n situatie zou voelen.

English translation (Google Translate):

This is a questionnaire about situations that you can experience at school and about your feelings in these kinds of situations.

We would like to ask you to complete this questionnaire and to answer as honestly as possible. The questionnaire is anonymous, which means that nobody will see your answers.

The stories in this questionnaire are about situations with your teacher at school. You may have never experienced such a situation, but you can imagine that someone else has experienced it and how you would feel in such a situation.

Eerst krijgen jullie verhaaltjes te horen. Daarna moet je vragen over het verhaaltje beantwoorden. / First you will hear stories. Then you have to answer questions about the story.

Als je dit plaatje ziet, betekent het dat jullie gaan luisteren naar een nieuw verhaaltje: / When you see this picture it means that you are going to listen to a new story:

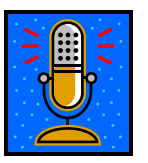

After listening to the story, continue with the questions. 
PART A / DEEL A

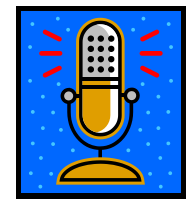

\section{Vraag A1/ Question A1 (vignette A1)}

a) Stel jij bent Peter. Hoe zou jij je voelen wanneer dit jou zou overkomen? / Suppose you are Peter. How would you feel if this happened to you? [open question]

b) Hieronder staan een paar mogelijkheden van hoe jij je zou kunnen voelen. Geef hieronder aan hoe jij je zou voelen: / Below are a few options of how you might feel. Please indicate how you would feel:

Hoe boos zou jij zijn? [How angry would you feel?]

$<----[1]$<smiles>C=[AsH2]</smiles>

Helemaal niet

[not at all]

\section{Een beetje}

[a little]

Best wel

[much]

Heel erg

[very much]

Hoe onzeker zou jij zijn? [insecure]
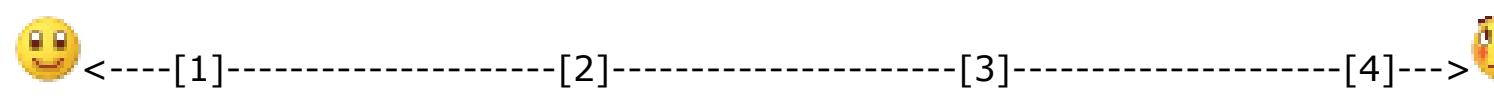

Helemaal niet

Een beetje

Best wel

Heel erg

Hoe teleurgesteld zou jij zijn? [disappointed]

$<----[1]$

Een beetje

Helemaal niet

(1)

Hoe geïrriteerd zou jij zijn? [irritated]

$<----[1]$

$[3]$

$[4]--->$

Helemaal niet

Een beetje
[3] $-[4]-->$

Best wel

Heel erg 
c) Stel jouw juf is de juf in dit voorbeeld. Hieronder staan een paar mogelijkheden van hoe jouw juf zich zou kunnen voelen. Geef hieronder aan hoe jij denkt dat jouw juf zich zou voelen. / Suppose your teacher is the teacher in this story. Below are a few options of how your teacher might feel. Please indicate below how you think your teacher would feel.

Hoe boos zou je juf zijn? [How angry would your teacher be?]

$<----[1]$ $[2]$

Helemaal niet [not at all]<smiles>C1C[IH][IH]1</smiles>

Heel erg [very much]
Best wel

[much]

Hoe teleurgesteld zou je juf zijn? [disappointment]

$<----[1]$

$[2]$

Helemaal niet
Een beetje

[a little]
[4]

Heel erg

d) Hieronder staan een paar mogelijkheden. Geef hieronder aan waarom jij denkt dat jouw juf zou zeggen dat je werkstuk niet aanvaardbaar is: / Below are a few options. Please indicate below why you think your teacher would say that your paper is not acceptable:

1. Omdat mijn juf mij onaardig vindt / because my teacher doesn't like me

Klopt helemal Klopt niet
niet $\begin{gathered}\text { Klopt een } \\ \text { beetje }\end{gathered} \quad \begin{gathered}\text { Klopt goed } \\ \text { Klopt erg } \\ \text { goed }\end{gathered}$

[not at all applicable][not applicable][a little applicable][fairly applicable][highly applic.]

2. Omdat mijn juf mij wil straffen / because my teacher wants to punish me

Klopt helemal
niet $\quad \begin{gathered}\text { Klopt een niet } \\ \text { beetje }\end{gathered} \quad \begin{gathered}\text { Klopt goed } \\ \begin{array}{c}\text { Klopt erg } \\ \text { goed }\end{array}\end{gathered}$

3. Omdat mijn juf mij oneerlijk behandelt / because my teacher treats me unfair

Klopt helemaal
niet $\quad$ Klopt niet $\begin{gathered}\text { Klopt een } \\ \text { beetje }\end{gathered} \quad \begin{gathered}\text { Klopt goed } \\ \begin{array}{c}\text { Klopt erg } \\ \text { goed }\end{array}\end{gathered}$

4. Omdat mijn juf weet dat ik beter kan / because my teacher knows I can do better

Klopt helemaal
niet $\quad$ Klopt niet $\quad \begin{gathered}\text { Klopt een } \\ \text { beetje }\end{gathered} \quad$ Klopt goed $\quad \begin{gathered}\text { Klopt erg } \\ \text { goed }\end{gathered}$




\section{PART B / DEEL B}

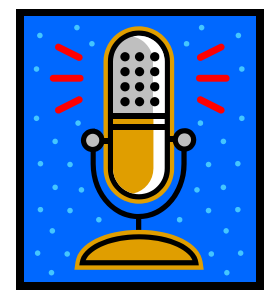

\section{Vraag 1B/ Question 1B (Vignette B1)}

- Stel jij bent Jan, zou je doen wat de juf zegt? / Suppose you are Jan, would you do what the teacher tells you to do?

Ja, zeker weten / yes, sure

Ja, ik denk het wel / yes, I think so

Nee, ik denk het niet / No, I don't think so

Nee, zeker niet / No, surely not

- Stel je bent Jan, vind je het belangrijk om hierover geen problemen te krijgen met je juf? / Suppose you are Jan, do you find it important not to have any problems with your teacher about this?

Helemaal niet belangrijk / Not important at all

Niet zo belangrijk / Rather not important

Best wel belangrijk / Rather important

Heel belangrijk / Very important

Dit verhaaltje is ook aan andere kinderen verteld. Er was iemand die zei: Ik zou met de juf gaan praten. Geef hieronder aan of jij dat ook zou doen. / This story has also been told to other children. There was someone who said: I would talk to the teacher. Indicate below whether you would do the same.

- Zou jij met de juf gaan praten? / Would you go talk with your teacher?

Ja / yes

Misschien / maybe

Nee / no

Note: questions are repeated for each vignette. The complete questionnaire is available upon request 